\title{
THE ROLE OF THE ERGONOMICS ON APPAREL SECTOR WITHIN THE DEVELOPING TECHNOLOGY
}

\author{
Özlem KAYA ${ }^{*}$
}

${ }^{1}$ Hitit University, Faculty of Fine Arts, Design and Architecture, Department of Textile and Fashion Design ORCID No: http://orcid.org/0000-0002-8572-6577

\begin{tabular}{ll}
\hline Keywords & Abstract \\
\hline Technological development & On every stage of our life, we observe technological developments on the products and \\
Ergonomics & communication instruments we use. In the world of technology that changes rapidly \\
Apparel sector & "Will the role of the ergonomics on design of human-machine systems lose its effect?" \\
Susiness systems & question might come to mind. We can declare that with the technological development \\
all over the world, as a practical science the ergonomics, that should be benefited from, & will not lose its importance, the intensity of the research will increase from the physical \\
ergonomics towards the cognitive ergonomics. With the technological development, in & fact the human benefits from the technological change while evaluating the systems \\
those include many parameters, but the last decision maker is human as usual -and as \\
in all the automatic systems- the human maintains its crucial role in every kind of \\
system. It is possible to state that hybrid human-machine systems those compose of \\
various elements and can be solved, when needed, with deterministic, probabilistic and \\
fuzzy models will become more complex via high level technology. For instance, if the \\
humans and the robots are working together in a production system, in case of a \\
malfunction in production, a robot that does not stop like human might cause much \\
bigger destruction in production or business systems security. In this study, we tried to \\
examine from various perspectives the changing process and the role of the \\
ergonomics in apparel sector's business life within the technological development over \\
the world.
\end{tabular}

\section{GELİŞEN TEKNOLOJİ İÇİNDE ERGONOMİNİN HAZIR GIYYIM SEKTÖRÜNDEKİ} ROLÜ

\begin{tabular}{l} 
Anahtar Kelimel \\
\hline Teknolojik gelişim \\
Ergonomi \\
Hazır giyim sektörü \\
Isss sistemleri \\
Sistem kontrolü
\end{tabular}

\section{Öz}

Yaşantımızın her düzeyinde kullandığımız ürün ve iletişim araçları olarak teknolojik gelişimler gözlenmektedir. Çok hızla değişen bu teknoloji dünyasında "acaba gelecekte insan makina sistemlerinin tasarımında ergonominin rolü azalır mı" diye bir soru hatıra gelebilir. Tüm dünyada teknolojinin gelişimi ile birlikte ergonominin her alanda yararlanılması gereken bir uygulamalı bilim olarak öneminin hiç de azalmayacağını, buna karşılık fiziksel ergonomiden bilişsel ergonomiye doğru araştırma yoğunluğunun artacağını söyleyebiliriz. Insan teknolojik gelişim ile birlikte birçok parametrenin içinde yer aldığı sistemlerin değerlendirilmesinde teknolojik değişimden yararlanmaktadır ama her zaman olduğu gibi son karar verici yine insandır - ve tüm otomatik sistemlerde olduğu gibi - her türlü sistem içinde insan önemli rolünü korumaktadır. Çeşitli elemanlardan oluşan ve gerektiğinde belirli (deterministic), olasılıksal (probablistic) ve bulanık (fuzzy) modellerle çözülebilen hibrit insan makina sistemlerinin ileri teknoloji ile daha da çok karmaşıklaşacağı söylenebilir. Örneğin bir üretim sisteminde insan ve robotlar birlikte çalışlyorsa bir aksaklık halinde insanlar gibi durmayan bir robot, üretimde ve iş sistemlerinin güvenilirliğinde çok daha büyük yıkımlara yol açabilir. Bu çalışmada dünyadaki teknolojik gelişim içinde ergonominin hazır giyim sektörü iș yaşantısındaki değişim süreci ve rolü çeșitli açılardan irdelenmeye çalıșılmıştır.

\begin{tabular}{llll}
\hline Araştırma Makalesi & & Research Article & \\
Başvuru Tarihi & $: 15.08 .2019$ & Submission Date & $: 15.08 .2019$ \\
Kabul Tarihi & $: 09.10 .2019$ & Accepted Date & $: 09.10 .2019$ \\
\hline
\end{tabular}

\footnotetext{
*Sorumlu yazar e-posta: ozlemkaya@hitit.edu.tr
} 


\section{Introduction}

International competitive arena leaves Turkey only with one particular path to follow. This is a path of being scientific in all aspects of social life as well as in all technical and social issues and to benefit from the guidance of science. In all production and management systems, it should be the most crucial goal to make use of modern scientific techniques and to act in accordance with these scientific methods in the decisions to be taken.

Ergonomics is one of the most important areas of interest in the fields of industrial engineering such as occupational health and safety, efficient and productive work, total quality management, environmental protection, benchmarking, continuous improvement, continuous improvement, teamwork, strategic management, logistics, and human resources management.

Human, which is an important production factor in the production of economic products and services in businesses, is the most valuable asset of a given business. This insight has begun to be better understood through the transition from traditional management to modern management. While the upper hand of human has a positive effect on productivity, it has also added more significance to Ergonomics, which is a branch of science that allows the employee to work more comfortably, with less fatigue and less exposure to work accidents and occupational diseases.

In Greek, as is known, 'ergon' means work and 'nomos' refers to law. According to the detailed account by Chapanis (1995), ergonomics exposes knowledge of human behavior, ability, limit and other attributes for productive, safe, comfortable and effective human use and applies it to the design of tools, machines, systems, work, and environments. It also implies the application of biological information in the fields of anatomy, physiology and experimental psychology so as to attain the humanmachine-environment system, which balances the workload and working power in the best way and protects the employee's health and increases the production (Dul and Weerdmeester, 2001).

When we look at the areas of interest of ergonomics, it is seen that the following issues are prioritized.

- Physical issues related to Human-machine system

- Metaphysical issues related to Humanmachine system

- Workplace design and the work area layout

- Physical environment
- Psychological environment

- Choosing a task design, training

Ergonomics, in a system which includes human, examines the relationship between human and the other elements of the system in a scientific manner and aims to create a humane environment in which people feel better by means of theoretical principles and design methods and maximize the performance of the system. The work system or the humanmachine system encompasses all kinds of tools and materials, processes, physical and psychosocial environment. It performs tasks such as minimizing the effort put by a human during the work,

- Assigning the human to a work that is most compatible with his/her natural capabilities

- Ensuring optimum interaction between machine, human and environment

- And minimizing the effort put by a human during the work.

Ergonomics, which aims to examine the business systems in a scientific way, aims to minimize the extra effort put by the human during the work. One of the main goals of ergonomics is to increase the efficiency of the human - machine combination and increase the safety of work. Ergonomics, which aims to organize the method in a methodical way, is also aimed at ensuring that the work handled by tools and machines used by humans is compatible with the human characteristics.

Ergonomics, which mainly uses anatomy, physiology, psychology, social sciences, and engineering sciences, attempts to reach general laws through the methods peculiar to itself and through research methods. While working on empirical values with experimental results in laboratories, on one hand, it transforms the data obtained from applications into systematic information. Studies demonstrate that allowing human to work humanely in his/her natural comfort within the limits of human work, preventing work accidents that cause billions of \$ each year human accidents and large social demolition (Sanders and McCormick, 1993), creating a decent work environment for human dignity are among the main objectives of Ergonomics.

Ergonomics, on the one hand, provides the humanmachine system to work with maximum performance as applied science, and on the other hand, as one of the professional sciences, it examines the necessities of human to work in good conditions. 
Applied Ergonomics is defined as the examination of the necessary conditions and capabilities of human beings and the investigation of the necessary conditions for the adaptation of the work to the human and human to the work. What is crucial here is to combine productivity and rationality goals with the morale and the satisfaction of employees. Another meaning of this is to ensure the harmony between the employee and the job (between human and job and vice versa). In other words, no matter how advanced the machine used by a person, if the human-machine harmony cannot be achieved, it is not possible to achieve the high performance expected from the system formed by these two elements (Kroemer, et al, 2001).

It is important to provide ergonomic environment conditions in both production and office environments. In the field of production, especially in the works that are connected to the physical power, the actions of the employee during the execution of the work such as bending - reachingpulling - lifting - carrying should be monitored and studies on the minimization of these actions should be carried out (Figure 1). For example, if there is a movement that requires bending due to the execution of a given task, platforms that can move up / down can be designed to minimize this, or adjustments can be made at the belt and bench heights. If lifting and carrying are required, carrying can be employed through mechanical methods consider the weight of the lifted/ carried load (Dul and Weerdmeester, 2001).

Ergonomics practices have significant positive impacts on the workplace. These impacts will stand out as being able to work in a healthy and safe environment for the employee and will bring more production and profit for the employer. In particular, the humanity the work environment is as important as the employees' abilities, motivation, and education levels. In addition to being sufficient in terms of noise, lighting, ventilation, temperature, and humidity of the workspace, the physical suitability of the production system and the environment should also be handled ergonomically. A system that does not adequately assess the employee factor cannot be expected to be economical in the long term. No measure in production can be compared with the effectiveness of manpower. In this respect, adapting in a way that it is in favor of the employee as a whole is also a prerequisite for efficiency.

The establishment of an ergonomic working environment in a workspace starts with protecting the health of the human working in the machine production system while also ensuring their security (Ramsey, 1985). In order to increase the quantity and quality of the work performed, it is obvious that transforming the working environment into an environment that will make the employee happy and content will in return prove beneficial for the quality and efficiency of the product. In an environment created in line with contemporary ergonomic principles, tools and equipment should be designed according to human characteristics and skills and working methods and environmental conditions should be adapted to the human conditions. Thus, the employees will perceive the work they perform as meaningful, interesting and useful. Employees should be provided with the opportunity to use their abilities and to prove themselves as a 'value'.

As for the workspace infrastructure in terms of technological and spatial setup, it is significant to eliminate or at least minimize the elements that create stress or act as a source of stress. This process is an application that should be realized in the light of the science of ergonomics and is the basis of efficient working order. All elements such as healthy communication, healthy work, job satisfaction, productivity, and peaceful environment are shaped on this basis (Kaya, 2008).

Stating that the importance of ergonomics is still not fully understood in Turkey, Özok (2014a-2014b) puts forth the following statement: "International employers consider ergonomics when it comes to occupational health and safety. In our case, employers need to be more willing to do this and also our workers' unions should work on how their conditions can be improved."

Given the examples provided and the damages that may result from neglecting the science of ergonomics, in the context of today's economy where competitiveness and customer satisfaction have increasingly become significant, each enterprise that aims to survive, reach its peak success and attain increased efficiency by keeping the motivation of its employers high, should be mindful of the science of Ergonomics and adapt its working conditions to the basics of ergonomics.

\section{Ergonomic Developments in the Apparel Sector}

Turkey has adopted the export-oriented growth model. However, a rapid change and development process has started to take place simultaneously in local and international markets, as well as in global competition, market conditions and customer profiles, whose speed is constantly changing. In other words, competition in the market environment 
has turned to quality, technology, and brand more than export. Thus it was observed that Turkey's strategy solely based on export-competitiveness fails to provide continuous and sustainable increase export and increase in added-value and this in return has compelled Turkey, which aspires to get its place and share in global markets, to create more powerful brands in the market and to follow the technology.

The quality of working life can only be scientifically evaluated with an understanding of all factors that directly or indirectly affect human work. In addition to the method used in the study in terms of the system approach, the layout of the workspace, the design of tools, machinery and all other production tools, the physical and psycho-social environment of the working environment are factors that affect the satisfaction and efficiency of the employee. In addition to physical factors such as noise, lighting, toxic gas and dust, vibration, all psycho-social factors must be evaluated on a scientific basis. All responsible persons should know that corrections based on common sense or experience can be useful only for the scientific design of the workspace to a very limited extent (Kaya and Özok, 2012). With the developing technology in the apparel sector, the arrangements and the measures taken should ensure that the employees work in a safer and more convenient environment. In this way, the expected performance could be achieved. Also,

- The ergonomic design of the humanmachine system,

- Structure and quality of the raw material used,

- The applied production process,

- The degree to which the means of production are used,

- Continuity and standardization in production,

- Effective use of human power significantly affects system performance.

With the arrangements to be performed, business systems can be made more ergonomic and the problems that an employee may experience pertinent to work or workspace may be minimized.
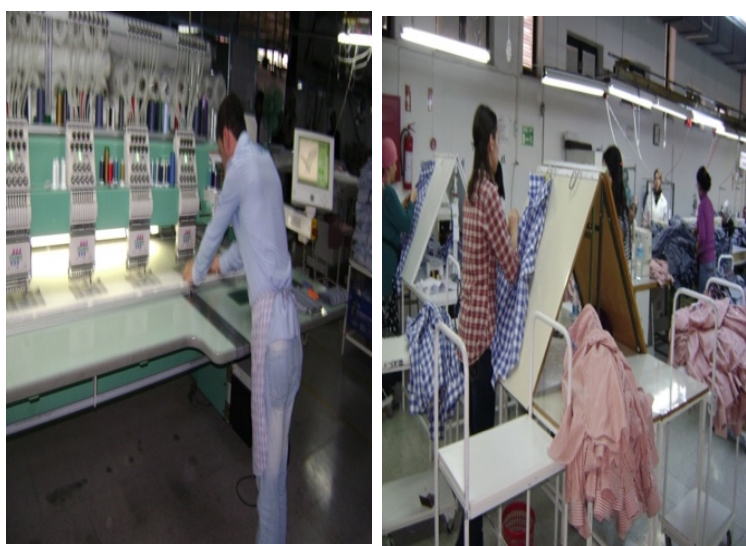

Photograph 1: Unergonomic Working Areas
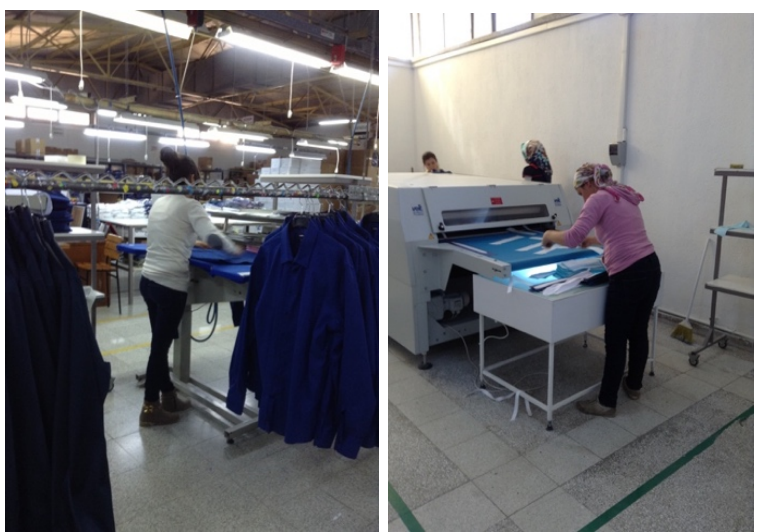

Photograph 2: Unergonomic Working Areas

When the photograph 1-2 are examined, it is seen that the employees working in the apparel sector work under unergonomic conditions and with unergonomic equipment.

However, Seitz (1996) stated that ergonomics practices provide significant gains in the workspace. These gains will allow employers to work in a healthy and secure environment for the employee and will bring more production and profit for the employer. 

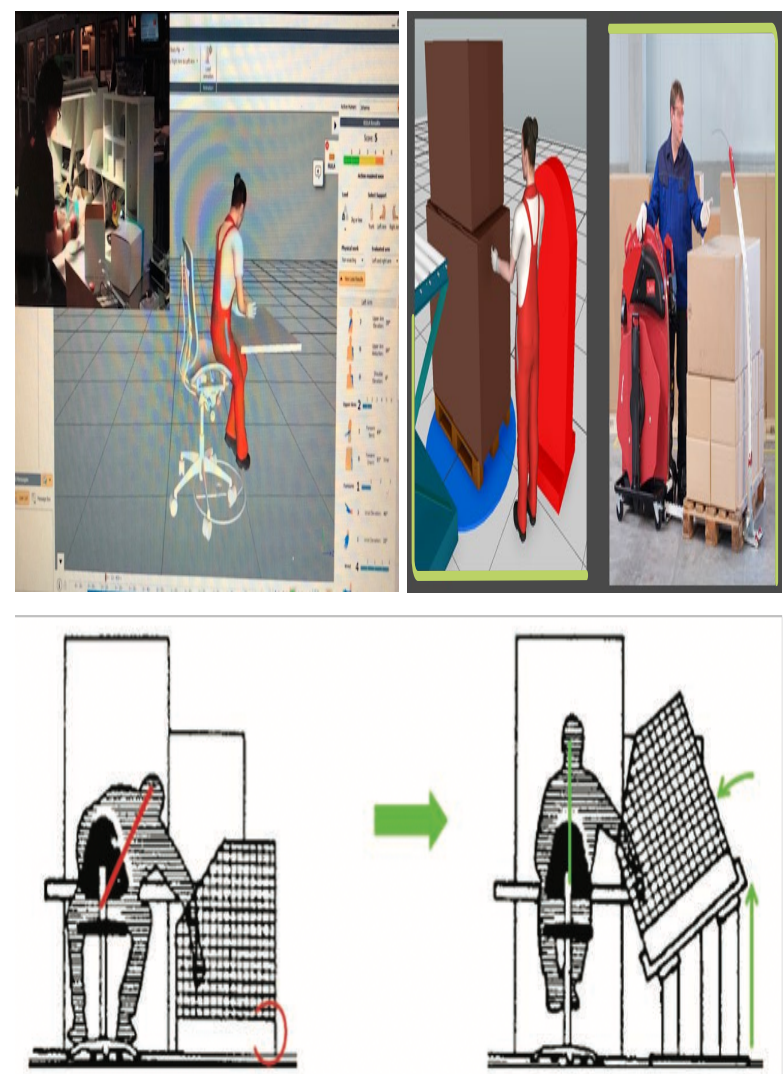

Figure 1. The Design of Workstations
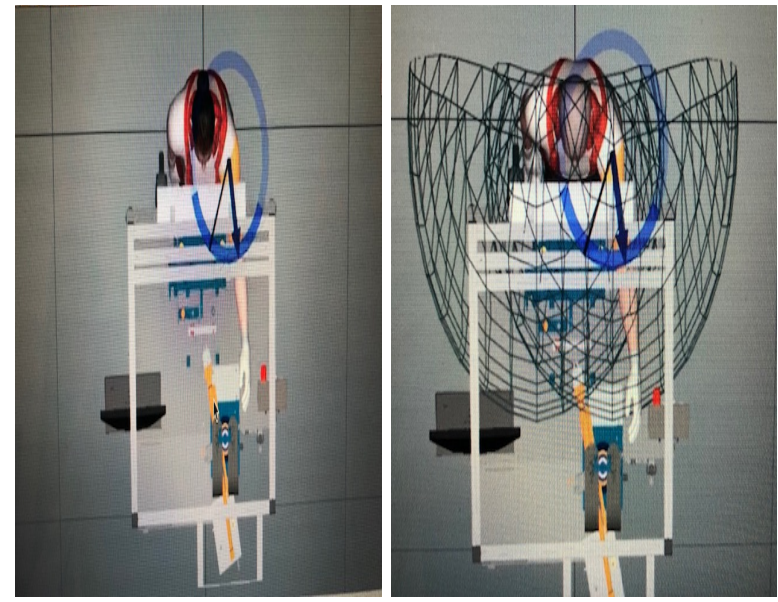

Figure 2. The Employee Working Place Design (Access points, with simulation)

Together with the developing technology, the change in the apparel sector should be followed and integrated into the sector. In this context, by means of computer-aided programs to minimize the burden on the employees, overly challenging cases could be identified with simulations and accordingly, due regulations and designs could be re-arranged. Considering these measurements, as shown in
Figure 2, it is necessary conduct studies to determine the areas accessible to the worker and which the points of his / her body are exposed to the movements such as reaching and pulling to access these areas This type of studies is a frequently used tool for designing workstations ergonomically worldwide.

The apparel, which plays a crucial role in the development of the economy and has a notable share in exports and generates employment, will grow further and, with the developing technology and the confidence brought by working under ergonomic conditions both for the laborer and the employer, it can take stronger steps for towards the future.

\section{Result}

When the factors resulting in problems for the employees in the apparel industry are analyzed, ergonomic hazards stand out to be one of the dangers that may occurring at a more intensive and higher frequency than the dangers in other sectors. The apparel industry is a sector that needs attention at every stage of production and needs to be worked closely with the material. In this respect, predetection of hazards and making necessary ergonomic arrangements will be useful in eliminating or reducing the risks that may come into being. Given the global technological advancement, Turkey's quest for designing the working conditions in accordance with the ergonomic principles and building the technological infrastructure do not seem quite difficult.

It should be noted that high employee satisfaction and efficiency can be achieved with ergonomically designed workspace. Therefore, the ergonomic design of the manual workspaces in production should be guaranteed and continuously improved. All countries in all over the world and Turkey in particular with its emerging industry should build up the necessary infrastructure in this regard and design them with an approach taking into consideration workstations and according the ergonomic implementations workers should train for the awareness of ergonomic working conditions.

\section{Conflict of Interest}

No conflict of interest was declared by the authors. 


\section{References}

Chapanis, A. (1995). Ergonomics in Product Development: A Personal View. Ergonomics, 38 (8): 1625-1638.

Dul, J., Weerdmeester, B. A. (2001). Ergonomics for Beginners: A Quick Reference Guide. Second Edition, Taylor\&Francis.

Kaya, Ö., Özok, A. F. (2012). İş Çevresinin Tasarımı ve Ergonomi. 18. Ulusal Ergonomi Kongresi Bildiriler Kitabı, 16-18 Kasım, Gaziantep Üniversitesi, Gaziantep.

Kaya, S. (2008). Ergonomi ve Çalışanların Verimliliği Üzerine Etkileri. Ar-Ge Bülten, İzmir Ticaret Odası, Ağustos, Kurumsal, s. 25.

Kroemer, K. H. E., Kroemer, H. B., Kroemer-El- bet, K. E. (2001). Ergonomics - How to Design for Ease and Efficiency. Second Edition, New Jersey: Prentice Hall.

Özok, A. F. (2014a). İş Kazalarını Önlemede "Ergonominin" Rolü, www.trthaber.com

Özok, A. F., (2014b). Sağlık ve Güvenlik Açısından Ergonomi. İTÜ Vakfı Dergisi, Ocak- Mart, Sayı: 63 www.ituvakif.gov.tr

Ramsey, J. (1985). Ergonomic Factors in Task Analysis for Consumer Product Safety. Journal of Occupational Accidents, 7: 113-123.

Sanders, M. S., McCormick, E. (1993). Human Factors in Engineering and Design. Seventh Edition, Singapore: McGraw-Hill Inc.

Seitz, C.. (1996). Your Health and Safety at Work: A Collection of Modules. Ergonomics, ILO. 